\title{
Responses of soil moisture in different land cover types to rainfall events in a re-vegetation catchment area of the Loess Plateau, China
}

\author{
Shuai Wang, Bojie Fu* , Guangyao Gao, Yu Liu, Ji Zhou \\ State Key Laboratory of Urban and Regional Ecology, Research Center for Eco-Environmental Sciences, Chinese Academy of Sciences, P.0. Box 2871, Beijing 100085, PR China
}

\section{A R T I C L E I N F O}

\section{Article history:}

Received 6 June 2012

Received in revised form 29 September 2012

Accepted 8 October 2012

\section{Keywords:}

Soil moisture

Re-vegetation

Ecohydrology

Land cover

Loess Plateau

\begin{abstract}
A B S T R A C T
Implementation of the Grain-for-Green project has resulted in significantly increased vegetative cover on the Loess Plateau of China during the past few decades. The plant communities influence soil moisture recharge and usage processes, particularly the input process, which is directly related to transformation of the limited precipitation into available soil water in the semi-arid Loess Plateau. A study to measure soil moisture dynamics of typical land cover types associated with precipitation events was conducted in a re-vegetated catchment area. Smart probes were inserted at 6 different depths below the ground surface under grass (Andropogon), subshrub (Artemisia scoparia), shrub (Spiraea pubescens), tree (Robinia pseudoacacia), and crop (Zea mays) vegetation to record volumetric soil moisture at 10-minute intervals for a period of 60 days during the growing season in 2011. The advance of the wetting front and total accumulated infiltrated water were measured. The rainfall events were sporadic with widely different intensities, and the soil moisture was replenished mainly by 3-4 heavy precipitation events during July and August. The mean soil moisture content profiles of the 5 vegetation types can be ordered as crop $>$ grass $>$ subshrub $>$ tree $>$ shrub and this relationship displayed time stability. The different land cover types clearly influenced the water infiltration and water input amounts in the re-vegetated area. The subshrub site showed the highest total infiltration amount (164 $\mathrm{mm}$ ) with precipitation $(227 \mathrm{~mm}$ ) during the study period. The grass site had an infiltration amount of $156 \mathrm{~mm}$. The tree site had a total precipitation of $154 \mathrm{~mm}$ and an infiltration amount of $97 \mathrm{~mm}$. The infiltration amount was $136 \mathrm{~mm}$ for the shrub site and was the lowest $(83 \mathrm{~mm})$ for the crop site. Natural grasses displayed a rapid infiltration rate and the wetting front was able to reach a greater depth.
\end{abstract}

(c) 2012 Elsevier B.V. All rights reserved.

\section{Introduction}

The catchment water cycle includes the processes of precipitation, plant interception, throughfall, stemflow, infiltration, evaporation and transpiration. The change in soil moisture content is the center of the whole cycle and the central and unifying theme in earth system studies (Legates et al., 2011). In terms of soil moisture changes, the water cycle processes can be divided simply into two parts: inputs and outputs (Qiu et al., 2011). Plant communities influence the temporal and spatial variability of soil moisture content through these two processes, particularly the input process, which is directly related to the transformation of the limited precipitation into the available soil moisture present in the root zone of the soil and available for plant utilization (Mahmood, 1996). In arid and semi-arid areas, precipitation is the only source of soil moisture. It is important to understand the rainfall infiltration

\footnotetext{
* Corresponding author. Tel./fax: + 861062923557.

E-mail address: bfu@rcees.ac.cn (B. Fu).
}

processes and amounts because they represent the initial stage of the small catchment water cycle (Wang et al., 2008).

The relationship between vegetation and water is the central theme of eco-hydrology, which has been widely discussed and is the subject of many important recent advances (Li, 2011). Soil moisture content has been shown to control the establishment of plant communities, which, in turn, influence soil moisture recharge and usage (Legates et al., 2011). Vegetation directly affects soil moisture inputs at the base of plant canopies through precipitation partitioning, i.e., the process whereby incident rainfall is divided into canopy interception, throughfall or stemflow (Li, 2011; Marin et al., 2000). The precipitation intercepted by plant canopies does not contribute to soil moisture recharge (Llorens and Domingo, 2007). Throughfall and stemflow inputs directly affect the spatiotemporal variability of soil moisture recharge (Durocher, 1990; Iida et al., 2005; Levia and Herwitz, 2005). All three of these processes depend on both biotic (canopy) and abiotic (climatological) factors, such as aboveground surface area and rainfall event characteristics (Levia and Frost, 2003, 2006). Infiltration, surface run-off and evapotranspiration have been identified as the key factors in determining soil moisture content (Wang et al., 2012). Murakami 
(2009) found that stemflow production can change with stand age. Li et al. $(2008,2009)$ evaluated the stemflow of three semiarid shrubs (Tamarix ramosissima, Caragana korshinskii and Reaumuria soongorica) and its effect on soil moisture enhancement in the semiarid Loess Plateau of China. Soil moisture content was found to be significantly higher in the root area around the shrub stem than in the area outside the shrub canopy. This study showed that shrub stemflow conserved in the deep soil layers can be an available moisture source for plant growth under arid conditions and that root channels were preferential pathways for the movement of most stemflow water into the soil. Similar experiments by Pan and Wang (2009) and Wang et al. (2011b) gave consistent results. Small rainfall events usually affect only the uppermost $\mathrm{cm}$ of the soil and easily lost through direct evaporation, and the soil moisture was therefore mainly contributed by the large events (Schwinning and Sala, 2004). The soil moisture content patterns of the vegetation types in the semiarid area of the Loess Plateau were well studied and documented during the past few decades. The studies indicate that bare soils have higher soil moisture contents than vegetated soils and that annual crops and grasses have higher soil moisture contents than forests (Fu et al., 2003; Qiu et al., 2001).

Over the past century, population growth has resulted in fragmentation and degradation of the environment of the Loess Plateau (Fu et al., 2000; Su et al., 2011). Beginning in 1998, the Chinese government implemented the Grain-for-Green project to prevent further deterioration of the natural ecosystems in the Loess Plateau region. One of the most pressing tasks of this project involves the recovery of the vegetation because of its crucial role in soil conservation (Wei et al., 2012). Re-vegetation can result in the increase of vegetation cover (Xin et al., 2008), improvement of soil nutrient levels (Zhou et al., 2008) and recovery of soil physical properties (Vallauri et al., 2002). However, re-vegetation also aggravated water scarcity (Wang et al., 2011a), which was one of the most prominent issues related to sustainable development. Addressing the trade-offs among water availability, grain production and carbon sequestration is the basis for ensuring the sustainable provision of ecosystem services in the Loess Plateau and requires a detailed understanding of the eco-hydrological processes involved. The patterns of rainfall common in the Loess Plateau are characterized by high intensity rainfall leading to an excess of water in a short period of time (Liu et al., 2012). A high runoff ratio enhances soil erosion and reduces soil moisture input. Thus, the capacity of a soil for rainwater infiltration and storage is of great importance in determining the amount of runoff and soil moisture storage for plant production.

Many studies have confirmed the recovery of vegetation resulting in the reduction of runoff on a regional scale (Sun et al., 2006; Wang et al., 2011a,c) and of soil desiccation on a local scale (Chen et al., 2008 ) in the Loess Plateau. These studies have focused on the increase of evapotranspiration (ET) caused by vegetation recovery when the input processes were not sufficient. Soil moisture dynamics have received considerable attention in recent decades (Fu et al., 2003; Gao et al., 2011; Hu et al., 2009). Previous studies have shown that infiltration processes can be more reliably captured by time series soil moisture content measurements using time domain reflectometry than by other methods (Jones et al., 2002; Wang et al., 2008). However, data on the infiltration processes and the effects of cumulative infiltration on different land covers remain scarce. The objectives of the present study were to analyze the characteristics of the precipitation in the northern Loess Plateau, observe the water infiltration processes by time series soil moisture content measurements under a heavy rainfall, and compare the effects of different soil moisture inputs of five typical plant species. In particular, we examined the soil moisture transport process to characterize the basic ecohydrological environment, clarify the effect of typical vegetation on rainfall partitioning, and understand the differences in soil moisture content from sources. We monitored real-time rainfall and soil moisture profiles for five plant species in the Loess Plateau of northern Shaanxi Province, China.

\section{Materials and methods}

\subsection{Study site description}

The study was performed in the Yangjuangou catchment $\left(36^{\circ} 42^{\prime}\right.$ $\mathrm{N}, 109^{\circ} 31^{\prime} \mathrm{E}$ ) located in Yan'an City of Shaanxi Province, in the central part of the Loess Plateau (Fig. 1). The total area was $2.02 \mathrm{~km}^{2}$, with slope gradients ranging from $10^{\circ}$ to $30^{\circ}$ and elevations ranging from 1050 to $1298 \mathrm{~m}$, and represents a typical loess gully and hilly geomorphology (Liu et al., 2012). The area has a semi-arid continental climate with a mean annual precipitation of $498 \mathrm{~mm}$ and a mean air temperature of $10.6{ }^{\circ} \mathrm{C}$ during the past 20 years (1988-2007). The rainfall is concentrated mainly between June and September and spring and early summer are usually characterized as the dry season. The growing season for most deciduous plant species ranges from April to October. The soil in the study area is derived mainly from loess and has a depth of 50-200 m depending on the topography. The loess in this area usually has a composition of more than $50 \%$ silt $(0.002-0.05 \mathrm{~mm})$ and less than $20 \%$ clay $(<0.002 \mathrm{~mm})$, and a porosity of approximately $50 \%$. The gravimetric field capacity and wilting percentage of soil moisture are $20-24 \%$ and $3-6 \%$, respectively (Du et al., 2011).

The land use in the Yangjuangou watershed before was dominated by crop lands. Driven by the implementation of the Grain-for-Green project since 1998, most of the cultivated lands on steep slopes were gradually abandoned for natural and artificial re-vegetation. Currently, the typical landscape pattern in the Yangjuangou catchment is a mosaic of patchy land cover. Grass and forest occupy most portions of the hill slopes. Shrubs dominate the bottoms of the north-facing slopes (Li, 2011). The major introduced forest species in this area is acacia (Robinia pseudoacacia), which was planted in the 1980s or after 1999. Artemisia scoparia, Stipa bungeana and Andropogon are the dominant subshrub and grass species. Spiraea pubescens and Hippophae rhamnoide are the major shrub species. Details of the study site were also documented by Liu et al. (2012) and Wang et al. (2010).

\subsection{Experimental design and data collection}

We chose five typical land cover types with similar slope positions, aspects, and slope degrees, except for the crop site (Fig. 1). The slope gradients of the sites were approximately $22^{\circ}$ with small differences. Soil samples were collected for particle size and bulk density measurement, and the plant morphology and cover were also measured. The tree site was planted with acacia (R. pseudoacacia) in rows with an interval distance of 2.5 or $3 \mathrm{~m}$. The site of shrub was covered by dense $S$. pubescens with a sparse layer of planted acacia. The site of subshrub was characterized by mosaic of $A$. scoparia coverage and interspersed bare areas. The site of grass was covered by beard Andropogon with imbedded bare areas. The site of crop was located on the dam land cultivated with corn (Zea mays) at the bottom of the valley (Table 1). The grasses and subshrubs grew in their natural succession.

To measure soil moisture content, H21 Soil Moisture \& Temp Logger Systems with 6 S-SMC-M005 soil moisture and 6 S-TMB-M006 temperature smart sensors (Decagon Devices Inc., Pullman, WA) were installed at depths of $10,20,40,60,80$ and $100 \mathrm{~cm}$ below the ground surface (Fig. 1). Data were collected by a HOBO weather station logger every $10 \mathrm{~min}$, and values of rainfall infiltration were calculated for the five sites. For probe installation, a pit of sufficient width was dug in the soil and the probes were inserted into the soil through the side of the pit and placed horizontally in the direction of maximum slope of the terrain. The pit was then carefully refilled, avoiding perturbations as far as possible, and the surface was contoured similarly to the surrounding slope. Each site was set up with the measuring devices described above at the end of April 2011, and measurements were begun 2 months later to allow the soil to settle. 

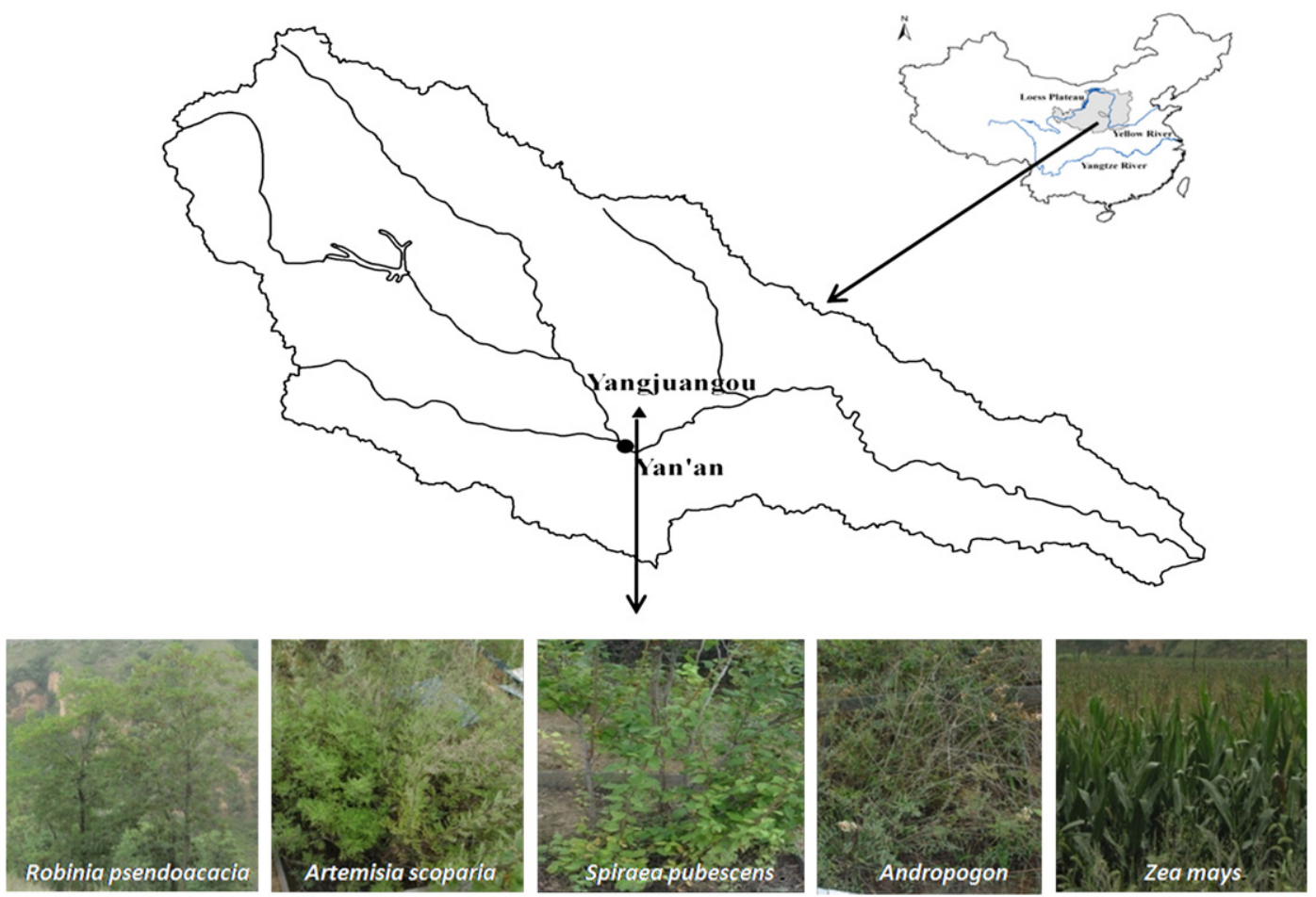

Fig. 1. Location map of the study area.

The soil moisture sensor is capable of measuring volumetric saturation values between $0 \%$ and $100 \%$, with an accuracy of $\pm 1.0 \%$ and a resolution of $0.1 \%$. Wang et al. (2008) suggested that the wetting front location can be detected by measuring the changes of water content in a soil profile. In the present study, the infiltration process was determined by measuring the changes of water content in a soil profile at depths of $10,20,40,60,80$ and $100 \mathrm{~cm}$, based on the assumption that the water reaches a certain depth when the soil moisture content begins to increase. The rainfall was measured using a tipping bucket rain gauge connected to a data logger with a precision of $0.2 \mathrm{~mm}$. Other meteorological parameters (air temperature, relative humidity, and wind velocity at a height of $2 \mathrm{~m}$ above the ground) were recorded every $30 \mathrm{~min}$.

\subsection{Data analysis}

Data on soil moistures of these five types were analyzed using SPSS for Windows 16.0. A one-way ANOVA was performed, after verifying the assumptions of normality and homogeneity of variances, to test the effects of land cover types on soil moisture.

The volumetric soil moisture content was measured with a probe matching the different depths of the soil profiles. Based on the principle of soil water balance, the cumulative infiltration can therefore be described as:

$I=\left(S_{e}-S_{i}\right) \times Z_{f}$

Table 1

Vegetation and soil characteristics of the 5 observed sites.

\begin{tabular}{lllll}
\hline $\begin{array}{l}\text { Observed } \\
\text { site }\end{array}$ & $\begin{array}{l}\text { Land cover type } \\
\text { (plant species) }\end{array}$ & $\begin{array}{l}\text { Cover } \\
(\%)\end{array}$ & $\begin{array}{l}\text { Height } \\
(\mathrm{m})\end{array}$ & $\begin{array}{l}\text { Soil bulk density } \\
\left(\mathrm{g} \mathrm{cm}^{-3}\right)\end{array}$ \\
\hline Site 1 & Robinia pseudoacacia & 40 & 5.5 & 1.36 \\
Site 2 & Artemisia scoparia & 75 & 0.45 & 1.25 \\
Site 3 & Spiraea pubescens & 90 & 1.5 & 1.22 \\
Site 4 & Andropogon & 80 & 0.4 & 1.29 \\
Site 5 & Zea mays & 95 & 2.2 & 1.40 \\
\hline
\end{tabular}

where $S_{e}$ is the volumetric soil moisture content $\left(\mathrm{cm}^{3} \mathrm{~cm}^{-3}\right)$ at the end stage, $S_{i}$ is the initial volumetric soil moisture content $\left(\mathrm{cm}^{3} \mathrm{~cm}^{-3}\right), Z_{f}$ is the infiltration depth $(\mathrm{cm})$, and $I$ is the cumulative infiltration $(\mathrm{mm})$.

\section{Results}

\subsection{Rainfall characteristics during the study period}

During the study period from July 1 to August 31, 2011, the total rainfall recorded was $227 \mathrm{~mm}$, accounting for approximately $46 \%$ of the average annual precipitation. A rainfall event has an interval of $2 \mathrm{~h}$, and there were 10 rainfall events for two months with $>3 \mathrm{~mm}$. The duration, amount and intensity characteristics of those rainfall events are presented in Table 2. The rainfall events during the study period in Yangjuangou were obviously sporadic in amount, duration, and intensity. The heaviest event occurred on July 29 and resulted in a total rainfall of $68 \mathrm{~mm}$, with a maximum 30-minute rainfall intensity of $5.23 \mathrm{~mm}$ and an average intensity of $3.5 \mathrm{~mm}$. The lightest rainfall event occurred on July 13, with a total rainfall amount of $3 \mathrm{~mm}$, a maximum 30-minute intensity of $0.9 \mathrm{~mm}$ and an average intensity of $0.65 \mathrm{~mm}$. These results suggest that some rainfall events involved

Table 2

Rainfall characteristics during July and August.

\begin{tabular}{llcclll}
\hline Order & Date & $\begin{array}{c}\text { Amount } \\
(\mathrm{mm})\end{array}$ & $\begin{array}{c}\text { Duration } \\
(\mathrm{min})\end{array}$ & \multicolumn{3}{l}{30 min intensity $(\mathrm{mm})$} \\
\cline { 5 - 7 } & & & Max & Min & Average \\
\hline 1 & 2-Jul & 17.6 & 1013 & 1.25 & 0.49 & 0.78 \\
2 & 4-Jul & 4.8 & 380 & 0.7 & 0.2 & 0.45 \\
3 & 13-Jul & 3 & 104 & 0.9 & 0.15 & 0.65 \\
4 & 24-Jul & 8.2 & 89 & 4 & 2.7 & 3.35 \\
5 & 26-Jul & 7.6 & 78 & 2.5 & 1.7 & 2 \\
6 & 29-Jul & 68 & 980 & 5.23 & 0.4 & 3.5 \\
7 & 17-Aug & 9.2 & 150 & 1.72 & 1.3 & 1.48 \\
8 & 18-Aug & 40 & 895 & 2.5 & 1.02 & 1.56 \\
9 & 19-Aug & 54.4 & 1500 & 1.185 & 0.655 & 0.985 \\
10 & 24-Aug & 14 & 304 & 3.1 & 1.6 & 2.67 \\
\hline
\end{tabular}


not only a small rainfall amount but also a high intensity. There were 3 rainfall events with a rainfall depth $>40 \mathrm{~mm}$ in July and August. Such events scarcely occurred in other months of the year.

The heaviest rainfall event was used to analyze the advance of the wetting front. The slope of the accumulated precipitation curve was relatively high. During the two months of the study, the recorded 30 -minute rainfall intensity was $>5 \mathrm{~mm}$ approximately $23 \%$ of the time, $4-5 \mathrm{~mm} 48 \%$ of the time, $3-4 \mathrm{~mm} 8 \%$ of the time, and $<3 \mathrm{~mm}$ $23 \%$ of the time.

\subsection{Dynamics of the mean soil moisture and precipitation profiles}

The temporal dynamics of the mean soil moisture and precipitation profiles of the five land cover types are shown in Fig. 2. The different land cover types displayed obvious differences in soil moisture content. The crop site always had the highest moisture content than other types $\left(p<0.001\right.$, LSD method), ranging from 0.22 to $0.28 \mathrm{~cm}^{3} \mathrm{~cm}^{-3}$, with an average value of $0.25 \mathrm{~cm}^{3} \mathrm{~cm}^{-3}$. The shrub site always had the lowest moisture content, ranging from 0.06 to $0.18 \mathrm{~cm}^{3} \mathrm{~cm}^{-3}$, with an average of $0.11 \mathrm{~cm}^{3} \mathrm{~cm}^{-3}$. The results for the tree site were similar to those of the shrub site $(p=0.004)$, significantly different from others $(p<0.001)$, but it missed from August 10. The results for the subshrub and grass sites were intermediate, and subshrub missed for 8 days from August 8 to 16. The results for the five sites can be ordered as crop $>$ grass $>$ subshrub $>$ tree $>$ shrub. In brief, results for the subshrub and grass sites were similar $(p=0.067)$ and were greater than those of the tree and shrub sites $(p<0.001)$. All the mean soil moisture content values responded positively to precipitation for the five land cover types during the study period, and the differences among them remained stable over time (Fig. 2).

\subsection{Advance of the wetting front}

The heaviest rainfall event, which occurred on July 29, was used to analyze the advance of the wetting front (Fig. 3). The tree site had the lower initial soil moisture content, and the driest soil layer at a depth of $20 \mathrm{~cm}$. The wetting front took approximately $20 \mathrm{~min}$ from the start of precipitation to reach a depth of $10 \mathrm{~cm}$. After 90 min with a nearly linear rapid increase, the soil moisture became constant at a value of $0.25 \mathrm{~cm}^{3} \mathrm{~cm}^{-3}$ after starting from $0.09 \mathrm{~cm}^{3} \mathrm{~cm}^{-3}$. After approximately $120 \mathrm{~min}$, the wetting front reached a depth of $20 \mathrm{~cm}$. The moisture content at the depths of both 10 and $20 \mathrm{~cm}$ later started to increase. After approximately $60 \mathrm{~min}$ of intense infiltration, the soil moisture content reached values of 0.32 and $0.25 \mathrm{~cm}^{3} \mathrm{~cm}^{-3}$, respectively, and then appeared to decline. At this site, it took approximately $420 \mathrm{~min}$ for the wetting front to reach a depth $>40 \mathrm{~cm}$. After 240 min of rapid increase, the moisture content caught up with and exceeded the value

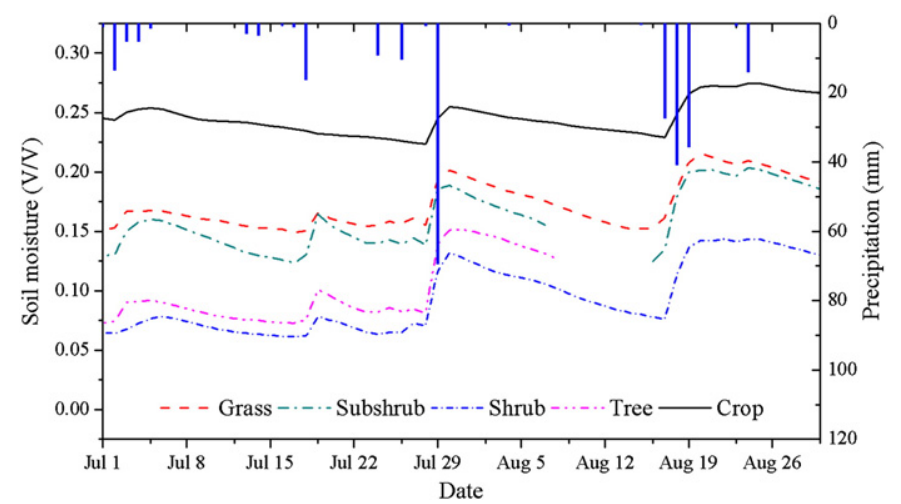

Fig. 2. Dynamics of the mean soil moisture and precipitation profiles during July and August. for the depth of $20 \mathrm{~cm}$, and became stable at $0.22 \mathrm{~cm}^{3} \mathrm{~cm}^{-3}$. The soil moisture content at a depth of $60 \mathrm{~cm}$ increased until one day later, and the content at the 80 and $100 \mathrm{~cm}$ depths did not change.

After rainfall lasted for more than $200 \mathrm{~min}$, the wetting front of the shrub site reached a depth of $10 \mathrm{~cm}$. The soil moisture content increased relatively slow. The wetting front took 340 min to reach a depth of $20 \mathrm{~cm}$. After approximately $90 \mathrm{~min}$ of rapid increase, the soil moisture content at a depth of $20 \mathrm{~cm}$ exceeded that at a depth of $10 \mathrm{~cm}$, and reached a constant value of $28.8 \mathrm{~cm}^{3} \mathrm{~cm}^{-3}$. Approximately $12 \mathrm{~h}$ later, the wetting front reached a depth of $40 \mathrm{~cm}$. After a period of slow increase, the soil moisture content reached a level of approximately $0.12 \mathrm{~cm}^{3} \mathrm{~cm}^{-3}$. The water infiltrated to a depth of $60 \mathrm{~cm}$ approximately 6 days later.

At the subshrub site, the wetting front reached a depth of $10 \mathrm{~cm}$ approximately $10 \mathrm{~min}$ later than at the tree site, but took almost the same time to achieve the first stable level, at $0.26 \mathrm{~cm}^{3} \mathrm{~cm}^{-3}$ after the initial $0.14 \mathrm{~cm}^{3} \mathrm{~cm}^{-3}$. The wetting front reached a depth of $20 \mathrm{~cm}$ approximately $100 \mathrm{~min}$ earlier than at the tree site, then quickly rose for approximately $50 \mathrm{~min}$ after similar processes of constant values and re-increase, reached maximum levels of 0.32 and $0.30 \mathrm{~cm}^{3} \mathrm{~cm}^{-3}$ slightly later than the tree site, and then began to decrease. Meanwhile, water infiltrated to a depth of $40 \mathrm{~cm}$ after $80 \mathrm{~min}$ of rapid increase to a constant value of $0.23 \mathrm{~cm}^{3} \mathrm{~cm}^{-3}$. The water reached a depth of $60 \mathrm{~cm}$ at the same time as for the tree site and ultimately reached a depth of $80 \mathrm{~cm}$.

The grass site had the lowest initial soil moisture content $\left(0.12 \mathrm{~cm}^{3} \mathrm{~cm}^{-3}\right)$ at a depth of $10 \mathrm{~cm}$. After approximately $40 \mathrm{~min}$ of rainfall, the moisture content at this depth began to increase. After approximately $370 \mathrm{~min}$ of rapid increase, the moisture content remained at a constant value of $0.24 \mathrm{~cm}^{3} \mathrm{~cm}^{-3}$ for $100 \mathrm{~min}$. Later, after $80 \mathrm{~min}$ of increase, it reached $28.5 \mathrm{~cm}^{3} \mathrm{~cm}^{-3}$. At this point the water had infiltrated to a depth of $20 \mathrm{~cm}$. After 160 min that included processes of sharp increase, constant value, and slow increase, the moisture content became constant at $0.21 \mathrm{~cm}^{3} \mathrm{~cm}^{-3}$. At this site, the wetting front took approximately 7 and $12 \mathrm{~h}$ to reach the depths of 40 and $60 \mathrm{~cm}$, respectively. The water infiltrated to a depth of $80 \mathrm{~cm}$ the next day and ultimately reached a depth of $100 \mathrm{~cm}$.

At the crop site, which had the highest initial moisture content, it took the wetting front approximately $300 \mathrm{~min}$ to reach a depth of $10 \mathrm{~cm}$. After $60 \mathrm{~min}$ of increase, the moisture content reached a constant value of $0.28 \mathrm{~cm}^{3} \mathrm{~cm}^{-3}$. The water infiltrated to a depth of $20 \mathrm{~cm}$ during a similar process and reached the same moisture content level. The moisture content at a depth of $40 \mathrm{~cm}$ later began to increase and reached a level of $0.33 \mathrm{~cm}^{3} \mathrm{~cm}^{-3}$. The water finally infiltrated to a depth of $60 \mathrm{~cm}$.

\subsection{The relationship between precipitation and cumulative infiltration}

Based on Eq. (1), for the heaviest rainfall event (on July 29), the cumulative infiltration $I(\mathrm{~mm})$ varied with the precipitation amount $P(\mathrm{~mm})$, as shown in Fig. 4. The relationships were linear for four of the sites and polynomial for one site. They can be presented mathematically as:

$$
\begin{aligned}
& I_{\text {tree }}=0.5 P-2.247 \\
& I_{\text {shrub }}=0.492 P-4.93 \\
& I_{\text {subshrub }}=-0.003 P^{2}+0.761 P-0.318 \\
& I_{\text {grass }}=0.123 P-1.135 \\
& I_{\text {grass }}=0.407 P-1.492 .
\end{aligned}
$$

During the two months of the study period, the subshrub site had a total precipitation of $227 \mathrm{~mm}$ and the highest infiltration amount 

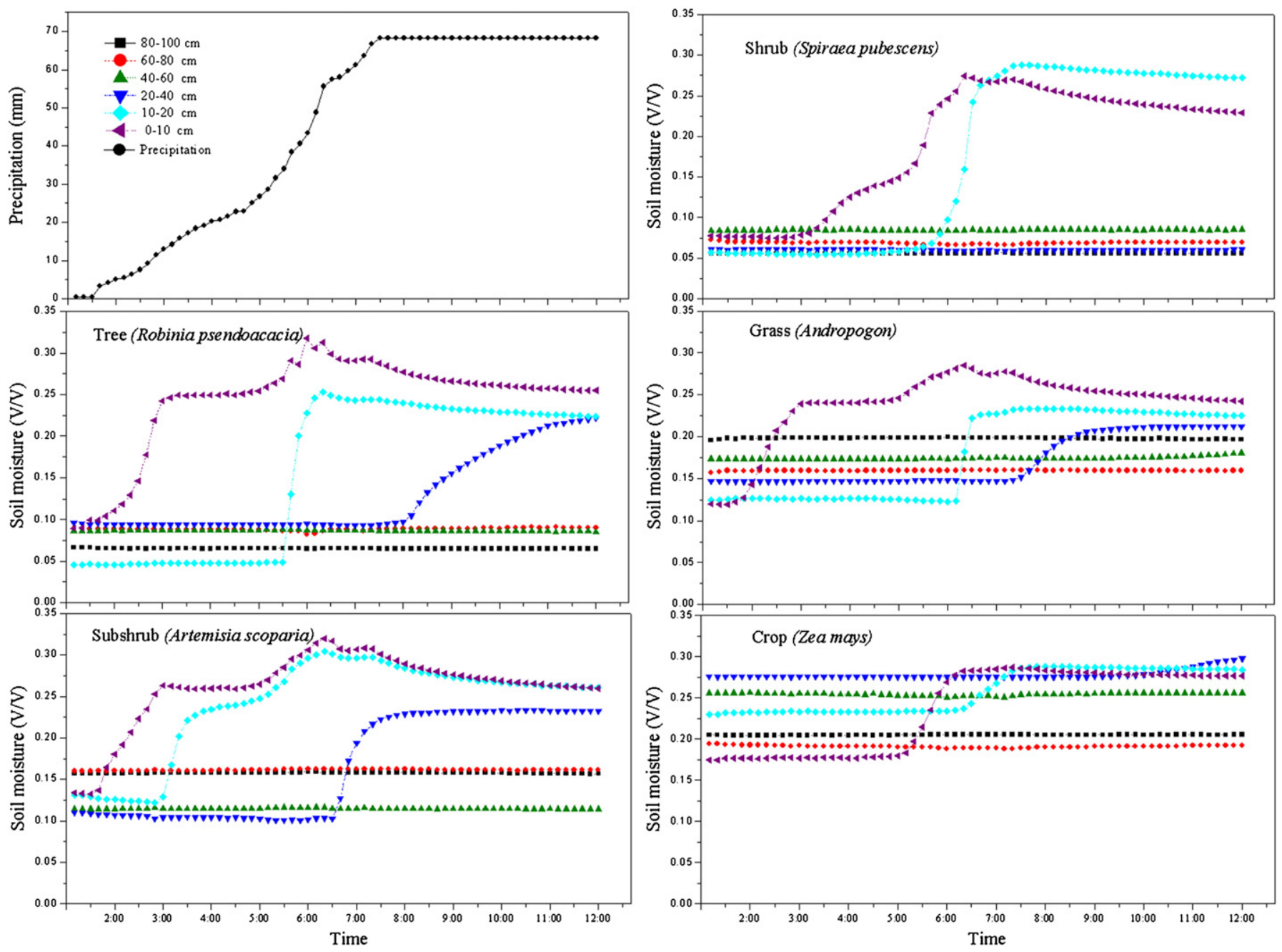

Fig. 3. The wetting front infiltration processes for the 5 land cover types.

(164 mm) and infiltration rate (approximately 72\%), followed by the grass site (infiltration amount $156 \mathrm{~mm}$, infiltration rate approximately $69 \%$ ). The tree site, for which data after August 8 were missing, had a total precipitation of $154 \mathrm{~mm}$, infiltration amount of $97 \mathrm{~mm}$ and infiltration rate of approximately $64 \%$. The shrub site had an infiltration amount of $136 \mathrm{~mm}$ and infiltration rate was approximately 60\%. The crop site had the lowest infiltration amount $(83 \mathrm{~mm})$ and infiltration rate (approximately 37\%) (Fig. 5).

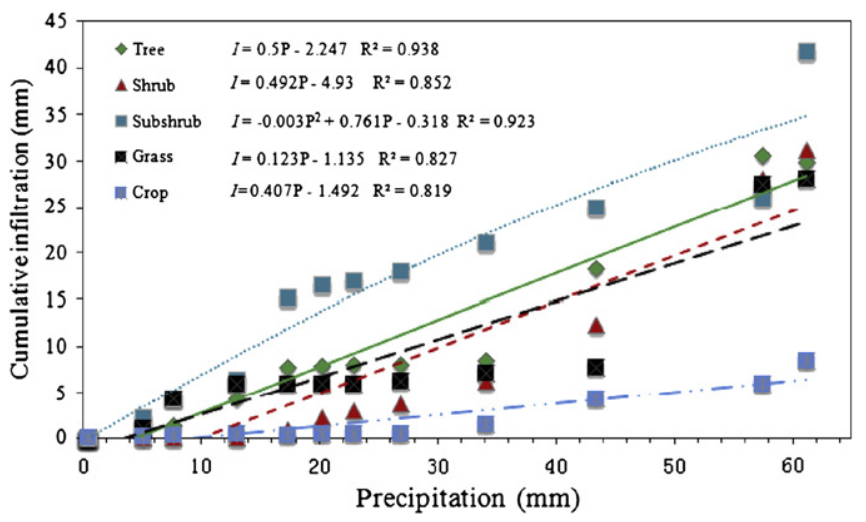

Fig. 4. The relationship between precipitation and cumulative infiltration.

\section{Discussion}

\subsection{Effective rainfall for the replenishment of soil moisture}

Agricultural production, domestic water supply and the natural vegetation depend mainly on the rainwater supply in the Loess Plateau

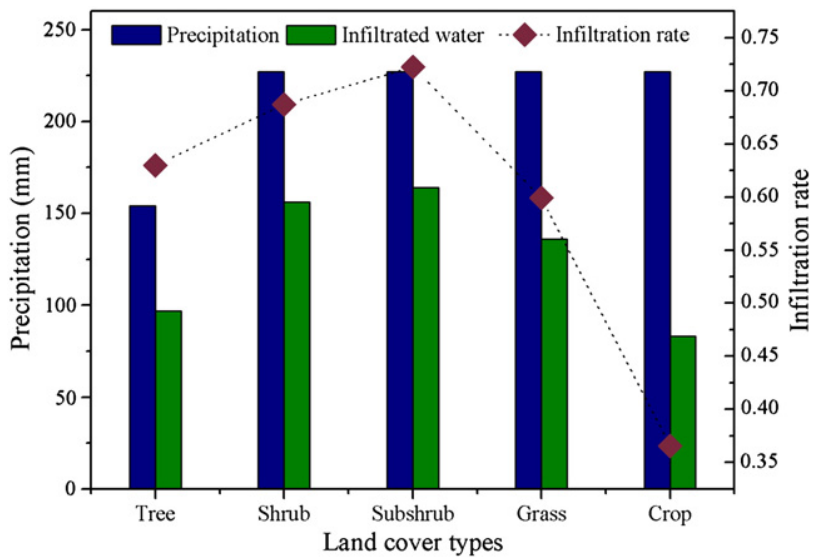

Fig. 5. Cumulative infiltration amounts and infiltration rates for the 5 land cover types during July and August. 
of northern Shannxi Province (Chen et al., 2003). The concentration of rainfall in the summer, together with high temperatures, is conducive to crop growth (Messing et al., 2003). Three consecutive years of meteorological data indicate that the period of this study (July to September) is the main period of precipitation for the year, accounting for approximately half of the annual precipitation (Liu et al., 2012). As shown in Fig. 2, the soil moisture content was replenished by 2-3 rainfall events of $>10 \mathrm{~mm}$. Conversely, the two rainfall events on July 26 and August 24 made almost no contribution to the soil moisture content. The relationship between increased soil moisture content and precipitation, and the thresholds for different land cover types are illustrated in Fig. 4. The soil moisture content increased during July to September, after the end of the growing season. Evapotranspiration losses were reduced and soil moisture accumulated throughout the rainy season, providing the basis for plant growth during the spring of the next year. Heavy rainfall usually has a large amount and a short duration, leading to high rainfall intensity and large floods, which cause severe soil erosion. Because of the restoration of vegetative cover and changes of soil properties in recent years, water runoff has begun to decline in the Loess Plateau. The adjustments in hydrological processes caused by land use changes are beginning to create a new ecological balance in this area.

\subsection{Differences in soil moisture and infiltration among land cover types}

The many native and cultivated plant species distributed in a mosaic fashion in the Yangjuangou catchment all have different morphological characteristics (Hu et al., 2010), soil water use efficiencies (Fu et al., 2003), soil nutrient and conservation effects (Fu et al., 2009; Wang et al., 2010), and soil moisture inputs. Understanding of these factors provides the basis for predicting the hydrological characteristics of hill slopes, catchments and other topographic features occupied by combinations of these plant species. There was a $10.5 \mathrm{~mm}$ rainfall during the week before this study began, resulting in a medium soil moisture content. There were significant differences among the initial soil moisture contents of the five study sites. The shrub site had the lowest value $\left(0.07 \mathrm{~cm}^{3} \mathrm{~cm}^{-3}\right)$, resulting from the dense shrub layer that consumed much shallow water. The soil moisture content of the tree site was higher than that of the shrub site because of the absence of a dense shrub layer. The highest soil moisture content was recorded on the dam land cultivated with corn (Z. mays) at the bottom of the valley. Dam land in the Loess Plateau is a unique and important invention designed for both food production and environmental purposes. Dams are constructed in the lower section of the valley. Accumulated silt is washed down from the mountains into reservoirs and finally into the farmlands for crop nutrition. Dam land is the primary arable farmland remaining after implementation of the Grain-for-Green project. With a higher nutrient content and water retention capacity, the soil moisture content of the crop site was as high as $0.223 \mathrm{~cm}^{3} \mathrm{~cm}^{-3}$ before the precipitation. The subshrub and grass sites represent the natural vegetative successions after abandonment of cultivation, i.e., the dominant native subshrub and grass species of the Yangjuangou catchment. They have similar soil moisture contents, in the medium range.

The soil moisture profiles display different vertical structures among the five sites. The infiltration process is controlled by several biophysical factors, including ground cover, soil type, hydraulic properties, rainfall intensity, and soil surface features (roughness and crusting) (Laio et al., 2001). The wetting fronts of the tree, subshrub, and grass sites reached a depth of $10 \mathrm{~cm}$ more quickly because they have a lower surface vegetation coverage. The advance of the wetting front was slower for the shrub site because of the dense shrub layer, and slowest for the crop site because of interception of the water by corn and because of greater soil viscosity. The wetting front advanced to a depth of $80 \mathrm{~cm}$ only at the grass site and to a depth of $60 \mathrm{~cm}$ at the other sites. The grass site had looser soil because it had been abandoned but it usually yields more runoff and finally has lower infiltration rate (Liu et al., 2012). Meanwhile, sparely distributed subshrubs acquire and retain soil moisture resources more quickly and efficiently than planted trees and dense shrub vegetation (Figs. 4. and 5). This is due to the efficient impediment effects and lower soil bulk density of subshrub vegetation, also gathered and maintained a high clay content (Wang et al., 2012). This leading to a competitive advantage in the long term for the subshrubs (Odindi and Kakembo, 2011), and make it representing an adaptive vegetative type in this area. Infiltration of the rainwater to deep soil took a longer time at the shrub and crop sites.

There was a negative correlation between the rate of increase of mean soil moisture content and the initial moisture content. The tree site had the highest mean soil moisture content increase, a rate of $0.07 \mathrm{~cm}^{3} \mathrm{~cm}^{-3}$, and a cumulative infiltration of $30 \mathrm{~mm}$. The lowest values were observed for the crop site, in which the mean soil moisture content increased to $0.03 \mathrm{~cm}^{3} \mathrm{~cm}^{-3}$. This site had a cumulative infiltration of $11 \mathrm{~mm}$ when the precipitation ended, but there was no runoff; the water remained stored in the soil surface. Therefore, dam lands exhibit a higher moisture content but a low permeability and a potential for salinization as higher bulk density and a clay layer in deep soils (Wang et al., 2012). Precipitation had a homogenizing effect on the soil moisture content of the catchment area, but it did not change the relationship between these five cover types. This relationship showed time stability even under heavy rainfall (approximately $70 \mathrm{~mm}$ ).

\subsection{Implications for soil and water conservation}

Increased water runoff causes serious soil erosion, and reduction of runoff by increased infiltration can therefore promote soil conservation. For the vegetation types studied, other than the crop, the water accumulated but did not infiltrate into the soil. The grass site had the lowest cumulative infiltration and the most runoff, consistent with previous findings that grass communities usually produce more soil loss. Following implementation of the Grain-for-Green project for more than 10 years, with the recovery of native and cultivated plant species, soil erosion in the Loess Plateau gradually decreased. Therefore, the research focus should be shifted to the water inputs and utilization characteristics of these typical vegetation species. Dam land is the paragon of effective use of water, and always maintains a high moisture content for crop growth. Artificially re-forested areas use more water, especially where they are covered with dense shrubs, because of the interception effect and reduced soil moisture input. Water infiltrated more quickly and was able to reach greater depths under the natural vegetation, particularly in the subshrub communities, which showed the highest cumulative water infiltration during the two month study period. Native plant species appear to be the most appropriate vegetation cover type.

\section{Conclusion}

The amount of rainfall in July and August accounted for approximately half of the total annual precipitation in the Loess Plateau of northern Shaanxi Province. Water was replenished in the soil mainly through 3-4 rainfall events with large amount, short duration and high intensity. This phenomenon is important for plant growth in the next year because this region generally has low precipitation in the spring. Infiltration was a significant process for the soil moisture budget. Most of the farmlands on the slopes of this region were abandoned during recent decades and were replaced by the natural succession of grass or subshrub species or planted forests and shrubs. Different plant communities differ in terms of water interception, stemflow, and root and soil properties, leading to various rainfall partitions and distinctive soil moisture input characteristics. Soil covered 
by natural grasses and subshrubs often have a high infiltration rate, and the wetting front can reach greater depths. The mean soil moisture content of planted forests has a greater rate of increase because the initial moisture content is lower, whereas dense shrubs intercept water and postpone the water infiltration, resulting in lower mean soil moisture content. Dam land has a high soil moisture content, although water takes a long time to infiltrate because of the higher crop cover and the soil composition.

\section{Acknowledgments}

This work was funded by the National Basic Research Program of China (no. 2009CB421104), the National Natural Science Foundation of China (nos. 40930528 and 41101096) and the CAS/SAFEA International Partnership Program for Creative Research Teams of "Ecosystem Processes and Services".

\section{References}

Chen, L.D., Messing, I., Zhang, S.R., Fu, B.J., Ledin, S., 2003. Land use evaluation and scenario analysis towards sustainable planning on the Loess Plateau in China. Catena 54 (1-2), 303-316.

Chen, H.S., Shao, M.A., Li, Y.Y., 2008. Soil desiccation in the Loess Plateau of China. Geoderma 143 (1-2), 91-100.

Du, S., Wang, Y.L., Kume, T., Zhang, J.G., Otsuki, K., Yamanaka, N., Liu, G.B., 2011. Sapflow characteristics and climatic responses in three forest species in the semiarid Loess Plateau region of China. Agriculture Forest Meteorological (1), 1-10 http:// dx.doi.org/10.1016/j.agrformet.2010.08.011.

Durocher, M.G., 1990. Monitoring of spatial variability of forest interception. Hydrological Processes 4, 215-229.

Fu, B.J., Chen, L.D., Ma, K.M., Zhou, H.F., Wang, J., 2000. The relationships between land use and soil conditions in the hilly area of the Loess Plateau in northern Shaanxi, China. Catena 39 (1), 69-78.

Fu, B.J., Wang, J., Chen, L.D., Qiu, Y., 2003. The effects of land use on soil moisture variation in the Danangou catchment of the Loess Plateau, China. Catena 54, 197-213.

Fu, B.J., Wang, Y.F., Lü, Y.H., He, C.S., Chen, L.D., Song, C.J., 2009. The effects of land-use combinations on soil erosion: a case study in the Loess Plateau of China. Progress in Physical Geography 33, 793-804.

Gao, X.D., Wu, P.T., Zhao, X.N., Shi, Y.G., Wang, J.W., Zhang, B.Q., 2011. Soil moisture variability along transects over a well-developed gully in the Loess Plateau, China. Catena http://dx.doi.org/10.1016/j.catena.2011.07.004.

Hu, W., Shao, M.A., Wang, Q.J., Reichardt, K., 2009. Time stability of soil water storage measured by neutron probe and the effects of calibration procedures in a small watershed. Catena 79, 72-82

Hu, C.J., Fu, B.J., Liu, G.H., Jin, T.T., Guo, L., 2010. Vegetation patterns influence on soil microbial biomass and functional diversity in a hilly area of the Loess Plateau, China. Journal of Soil Sediment 10, 1082-1091.

Iida, S., Tanaka, T., Sugita, M., 2005. Change of interception process due to the succession from Japanese red pine to evergreen oak. Journal of Hydrology 315, 154-166.

Jones, S.B., Wraith, J.M., Or, D., 2002. Time domain reflectometry measurement principles and applications. Hydrological Processes 16, 141-153.

Laio, F., Porporatro, A., Ridolfi, L., Rodriguez-Iturbe, I., 2001. Plants in water-controlled ecosystems: active role in hydrologic processes and response to water stress. Advances in Water Resources 24, 707-723.

Legates, D.R., Mahmood, R., Levia, D.F., DeLiberty, T.D., Quiring, S., Houser, C., Nelson, F.E., 2011. Soil moisture: a central and unifying theme in physical geography. Progress in Physical Geography 35 (1), 65-86.

Levia, D.F., Frost, E.E., 2003. A review and evaluation of stemflow literature in the hydrologic and biogeochemical cycles of forested and agricultural ecosystems. Journal of Hydrology 274, 1-29.

Levia, D.F., Frost, E.E., 2006. Variability of throughfall volume and solute inputs in wooded ecosystems. Progress in Physical Geography 30, 605-632.

Levia, D.F., Herwitz, S.R., 2005. Interspecific variation of bark water storage capacity of three deciduous tree species in relation to stemflow yield and solute flux to forest soils. Catena $64,117-137$.

Li, X.Y., 2011. Mechanism of coupling, response and adaptation between soil, vegetation and hydrology in arid and semiarid regions (in Chinese). Scientia Sinica Terrae 41, 1721-1730.
Li, X.Y., Liu, L.Y., Gao, S.Y., Ma, Y.J., Yang, Z.P., 2008. Stemflow in three shrubs and its effect on soil water enhancement in semiarid loess region of China. Agriculture Forest Meteorological 148, 1501-1507.

Li, X.Y., Yang, Z.P., Li, Y.T., Lin, H., 2009. Connecting ecohydrology and hydropedology in desert shrubs: stemflow as a source of preferential flow in soils. Hydrology and Earth System Sciences 13, 1133-1144.

Liu, Y., Fu, B.J., Lü, Y.H., Wang, Z., Gao, G.Y., 2012. Hydrological responses and soil erosion potential of abandoned cropland in the Loess Plateau, China. Geomorphology $138,404-414$.

Llorens, P., Domingo, F., 2007. Rainfall partitioning by vegetation under Mediterranean conditions. A review of studies in Europe. Journal of Hydrology 335, 37-54.

Mahmood, R., 1996. Scale issues in soil moisture modeling problems and prospects. Progress in Physical Geography 20 (3), 273-291.

Marin, T.C., Bouten, W., Sevink, J., 2000. Gross rainfall and its partitioning into throughfall, stemflow and evaporation of intercepted water in four forest ecosystems in western Amazonia. Journal of Hydrology 237, 40-57.

Messing, I., Fagerstrom, M.H., Chen, L.D., Fu, B.J., 2003. Criteria for land suitability evaluation in a small catchment on the Loess Plateau in China. Catena 54, 215-234.

Murakami, S., 2009. Abrupt changes in annual stemflow with growth in a young stand of Japanese cypress. Hydrological Research Letters 3, 32-35.

Odindi, J.O., Kakembo, V., 2011. The hydrological response of Pteronia incana- invaded areas in the Eastern Cape Province, South Africa. Ecohydrology 4, 832-840.

Pan, Y.X., Wang, X.P., 2009. Factors controlling the spatial variability of surface soil moisture within revegetated-stabilized desert ecosystems of the Tengger Desert, Northern China. Hydrological Processes 1591-1601.

Qiu, Y., Fu, B.J., Wang, J., Chen, L.D., 2001. Soil moisture variation in relation to topography and land use in hisope catchment of the Loess Plateau, China. Journal of Hydrology 240 (3-4), 243-263.

Qiu, G.Y., Xie, F., Feng, Y.C., Tian, F., 2011. Experimental studies on the effects of the conversion of cropland to grassland program on the water budget and evapotranspiration in a semi-arid steppe in Inner Mongolia, China. Journal of Hydrology http://dx.doi.org/ 10.1016/j.jhydrol.2011.09.040.

Schwinning, S., Sala, O.E., 2004. Hierarchy of responses to resource pulses in arid and semi-arid ecosystems. Oecologia 141, 211-220.

Su, C.H., Fu, B.J., Lü, Y.H., Lü, N., Zeng, Y., He, A.N., Lamparski, H., 2011. Land use change and anthropogenic driving forces: a case study in Yanhe River Basin. China Geographical Science 21, 587-599.

Sun, G., Zhou, G.Y., Zhang, Z.Q., Wei, X.H., McNulty, S.G., Vose, J.M., 2006. Potential water yield reduction due to reforestation across China. Journal of Hydrology $328,548-558$

Vallauri, D.R., Aronson, J., Barbero, M., 2002. An analysis of forest restoration 120 years after reforestation on Badlands in the southwestern Alps. Restoration Ecology 10 (1), 16-26.

Wang, X.P., Cui, Y., Pan, Y.X., Li, X.R., Yu, Z., Young, H.M., 2008. Effects of rainfall characteristics on infiltration and redistribution patterns in revegetation-stabilized desert ecosystems. Journal of Hydrology 358 (1-2), 134-143.

Wang, Y.F., Fu, B.J., Lü, Y.H., Song, C.J., Luan, Y., 2010. Local-scale spatial variability of soil organic carbon and its stock in the hilly area of the Loess Plateau, China Quaternary Research 73, 70-76.

Wang, S., Fu, B.J., He, C.S., Sun, G., Gao, G.Y., 2011a. A comparative analysis of forest cover and catchment water yield relationships in northern China. Forest Ecology and Management 262 (7), 1189-1198.

Wang, X.P., Wang, Z.N., Berndtsson, R., Zhang, Y.F., Pan, Y.X., 2011b. Desert shrub stemflow and its significance in soil moisture replenishment. Hydrology and Earth System Sciences 7, 561-567.

Wang, Y.H., Yu, P.T., Feger, K., Wei, X.H., Sun, G., Bonell, M., Xiong, W., Zhang, S., Xu, L., 2011c. Annual runoff and evapotranspiration of forestlands and nonforestlands in selected basins of the Loess Plateau of China. Ecohydrology 4, 277-287.

Wang, S., Fu, B.J., Gao, G.Y., Yao, X.L., Zhou, J., 2012. The hydrological responses of different land cover types in a re-vegetation catchment area of the Loess Plateau, China. Hydrology and Earth System Sciences 9, 5809-5835.

Wei, W., Chen, L.D., Yang, L., Fu, B.J., Sun, R.H., 2012. Spatial scale effects of water erosion dynamics: complexities, variabilities, and uncertainties. Chinese Geographical Science 22 (2), 127-143.

Xin, Z.B., Xu, J.X., Zheng, W., 2008. Spatiotemporal variations of vegetation cover on the Chinese Loess Plateau (1981-2006): impacts of climate changes and human activities. Science in China Series D-Earth Sciences 51, 67-78.

Zhou, P., Liu, G., Hou, X., 2008. Study on vegetation and soil nutrient characters of Artemisia sacrorum communities in hilly-gully region of the Loess Plateau. Acta Pratacultrae Sinica 17 (2), 9-18 (in Chinese with English abstract). 